\title{
Mechanical properties of carbon fiber reinforced polyamide produced by CFF method (Continuous Filament Fabrication)
}

\author{
Bartosz N owinka ${ }^{1 *}$ and Dariusz Sykutera ${ }^{1}$ \\ ${ }^{1}$ University of Science and Technology in Bydgoszcz, Faculty of M echanical Engineering, A I. prof. \\ S. K aliskiego 7, 85-796 Bydgoszcz, Poland
}

\begin{abstract}
The study presents the influence of content and orientation of continuous carbon fibers (CF) on the static tensile test results of a polyamide matrix (PA) composite, produced using Continuous Filament Fabrication (CFF) technology. Taking the polyamide's crystalline structure into account, an attempt was also made to produce test specimens under various temperature conditions of the device chamber. The test samples were produced in use of the M ark Two device (M arkforged, Great B ritain). It has been show $n$ that the content and orientation of the reinforcement in relation to the direction of stresses generated during the static tensile test, has a significant impact on the parameters determined in this test. The dependence presented in the article, confirms that materials in a thermoplastic matrix, reinforced with continuous fibers are a topic in line with the topic of current trends in fields of material engineering and design of structural products. The conducted research proves that the temperature in the working chamber of the Mark Two device affects formation of mechanical properties of $\mathrm{PA}+\mathrm{CF}$ composites, fabricated using CFF technology. M anufacturing composites at elevated temperature resulted in significant decrease of $\mathrm{E}$ and $R_{m}$ values for 4 out of five tests performed, but a considerable increase in their relative elongation at break was noticed.
\end{abstract}

\section{Introduction}

Carbon fibers are widely used in many branches of industry due to their excellent mechanical properties, in particular the longitudinal elastic modulus and low density in comparison to glass fibers. In the case of the latter, their dominant share in fibers market is a result of their advantageous price [1-2]. Boczkowska's research has shown that equally carbon and glass fibers are brittle, therefore they require setting in a polymer matrix, primarily a duroplastic one [3].

As the filling of polymer matrix, reinforcement in the form of continuous (roving, mats, textiles, UD textiles, tapes) or cut fibers is used. The use of continuous fibers strengthens composites more effectively, but they are most often used in various forms in the production of laminates [4-5]. Short fibers are used in the processing of thermoplastic polymers. This necessity arises from the fact that in the plasticizing system of the injection molding machine or extruder, fibers are cut into minor fragments as a result of process pressure and shear stresses. Furthermore, during the injection molding process, the molten material enters the injection mold cavity through a gate with a small cross-section. Presence of fibers with a length greater than the gate dimension will make the melt material encounter difficulty during mold cavity filling or even inability to flow into the mold. For that reason, composites obtained by the injection process are characterized by inferior mechanical properties which

* Corresponding author: B artosz.N owinka@utp.edu.pl 
is the result of inferior matrix-fiber adhesion, as well as the chaotic arrangement of fibers in the core part of samples [6].

The development of CFF (Composite Filament Fabrication) technology by Markforged made it possible to look again with optimism at manufacturing of thermoplastic composites, containing continuous fibers with a selected orientation as a reinforcement. The technology was patented in 2014 by Gregory Mark and Antoni Gozdz [7]. The CFF method belongs to the family of additive techniques that use filaments, known from FDM technology as the input material, in this case polyamide. Through applying two heads into the printer, it is possible to alternately dispense the molten matrix material without reinforcement or reinforced with a short CF fiber and filament containing continuous fibers (carbon, aramid, glass) in a polymer matrix. So far, several studies have characterized the mechanical properties of the composites obtained using CFF technology. The experiments of research teams led by Alwabel, Melenka, Dickson and Bitar [8-11] included static tensile tests. Compression and bending test were carried out by the Araya-Calvo team, and bending by Dickson with the team $[10,12]$. In the conducted studies of tensile properties, scientists focused on modifying process parameters, such as: use of supports, number of samples manufactured simultaneously, starting point of fiber application, fiber content, and a comparison of two different setups of reinforced layers in the composite structure in terms of their impact on the obtained mechanical properties. A matrix material in the form of Nylon was used, as well as continuous fibers: carbon, glass and Kevlar. The experiments showed that the change in the distribution of the reinforced layers, while maintaining the constant content of the reinforcement, may affect the mechanical properties under tensile forces, but these tests require deeper exploration, as only two variants of fiber distribution were compared. Bitar and his team investigated the impact of filament content on the Nylon $+\mathrm{CF}$ properties, but focused on adhesion between single layers by designing samples with layers stacked perpendicularly to the tensile forces.

The aim of the research was to determine the influence of the content and orientation of carbon fibers on the mechanical properties of a Nylon matrix composite, manufactured using CFF (Continuous Filament Fabrication) technique at two different working chamber temperatures. The assumption was that the temperature of the chamber and the direction of the fiber paths will significantly affect the strength parameters determined in the static tensile test $\left(R_{m}, E, \varepsilon\right)$.

\section{Research methods}

The materials used in the research were polyamide 6 under the trade name Nylon and carbon fibers, which are products of the Markforged company (Markforged, Great Britain). The continuous form of fiber was used for samples preparing. The device responsible for specimens manufacturing was continuously fed by two filaments with diameters of $1.75 \mathrm{~mm}$ and $0.35 \mathrm{~mm}$. The first one (FA designation) was polyamide 6 . The second filament (FB designation) was a continuous carbon fiber in a polyamide matrix (coating). According to the material's data sheet offered by the manufacturer, carbon fibers are characterized by a tensile strength of $800 \mathrm{MPa}$ and a Young's modulus of $60 \mathrm{GPa}$. Taking into account the moisture absorption of polyamide, the FA filament was unwound from a spool located in a special thermos (Fig.1a). The samples were produced in the $M$ ark Two device ( $M$ arkforged, Great $B$ ritain) with the CFF additive technique (Fig. 1a). The 3D printer was equipped with a closed working chamber with dimensions of $584 \times 330 \times 355 \mathrm{~mm}$ and with two working heads. According to the assumed research program, working heads applied successive layers of molten material on the working platform that allows print elements with maximum dimensions of $320 \times 132 \times 154 \mathrm{~mm}$. The M ark Two device is not equipped with the function of changing the temperature inside the chamber. It was considered that due to the presence of a crystalline phase in the polyamide's structure, it was advisable to carry out tests both at 
ambient temperature (standard) and at elevated temperature. Elevating working chamber's temperature was conducted with use of heating tables, usually used in the construction of 3D printers. Additionally, a system for measuring and controlling the temperature was applied (Fig. 1b). Heating elements were regulated by the program implemented to A rduino M ega microprocessor (manufacturer A rduino Software). Stabilization of the temperature in the chamber was carried on with the use of a thermistor and a temperature controller (Fig. 1b). The chamber of the device was tightly sealed with an aerogel (silica aerogel).

a)

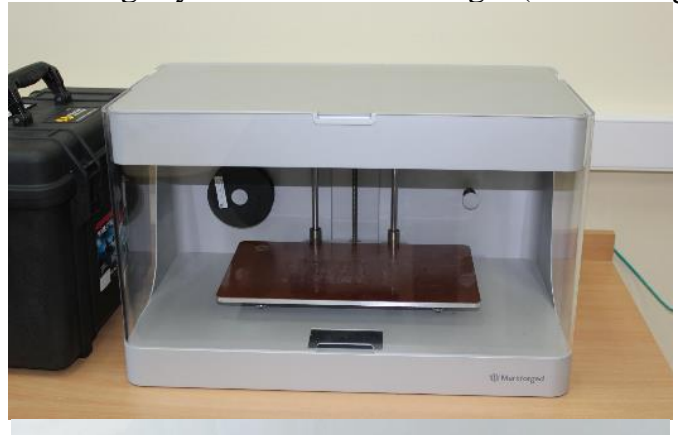

b)

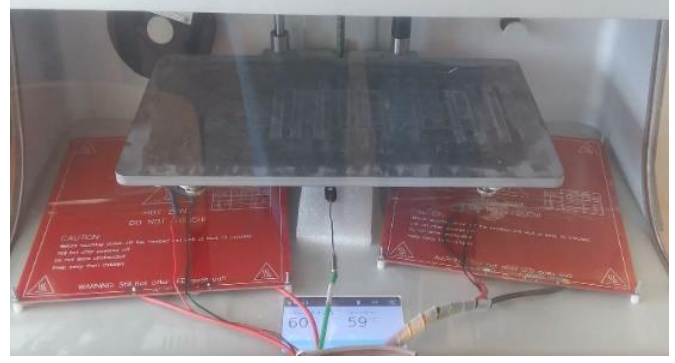

Fig. 1. Mark Two device (a) and the additional elements of the test stand used in experiments (b).

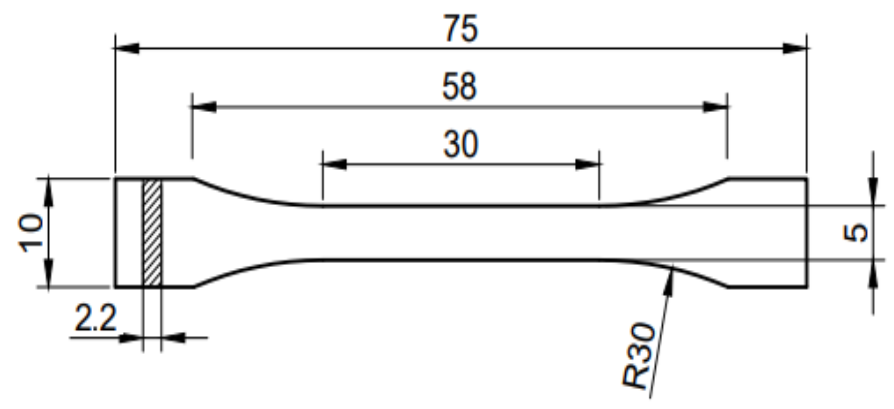

Fig. 2. Dimensions of test specimens produced in CFF technology.

Test specimens in CFF additive technique with dimensions of $75 \times 10 \times 2.2 \mathrm{~mm}$ (accordance to PN EN ISO 527-2:2012) were made (Fig. 2). The quotient of sample thickness and print resolution equal to $125 \mu \mathrm{m}$ was the basis to calculate a number of layers which had to be stacked one after another to achieve appropriate geometry. Obtaining specimen thickness equal to $2.2 \mathrm{~mm}$ required applying 18 layers of molten $\mathrm{PA} / \mathrm{CF}$ filament. The algorithm of layers applying excluded the possibility to apply continuous carbon fiber in the first and the last print layer. The experiment involved determining the method of subsequent layers applying, including selection of the number of continuous carbon reinforced layers and the direction of continuous fiber filament arrangement (Fig. 3). There were 6 variants adopted which diagram is shown in table 1 . The white cell (area) means a layer applied with 
use of polyamide filament. The dark (blue) one is equivalent to the layer with the participation of carbon fiber. The choice of reinforcement location and of orientation angles in the volume of specimen was made in accordance to previous research, performed with use of glass fibers (Nowinka, 2018; Jurek, 2018) [13-14].

a)

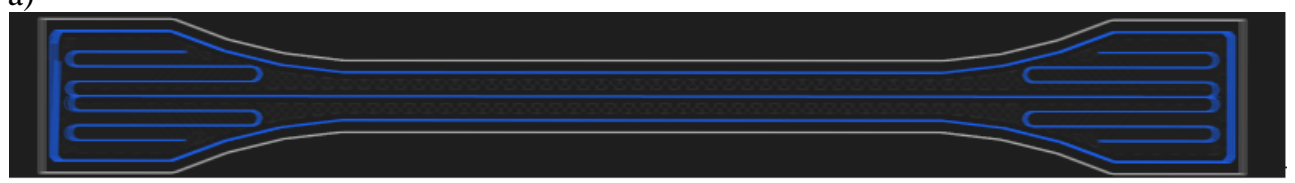

b)

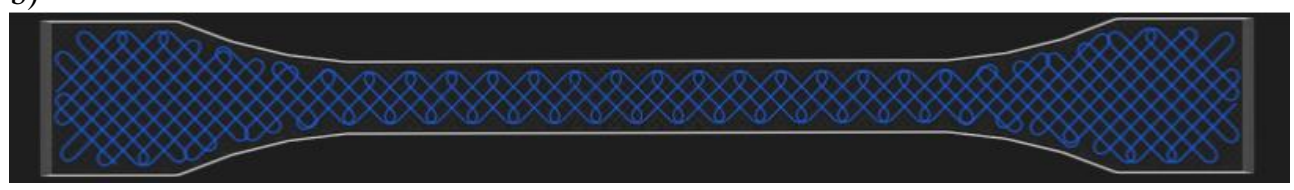

Fig. 3. A rrangement orientation of continuous carbon fibers (at the top (a) orientation angle $0^{\circ}$, (b) bottom $45^{\circ} / 135^{\circ}$ ).

Table 1. The reinforcement distribution for individual test series.

\begin{tabular}{|c|c|c|c|c|c|c|c|c|c|c|c|c|c|c|c|c|c|c|c|}
\hline $\begin{array}{c}\text { Series/ } \\
\text { Fiber } \\
\text { orientation }\end{array}$ & $\begin{array}{c}\text { Reinfor- } \\
\text { cement } \\
\text { layers }\end{array}$ & 1 & 2 & 3 & 4 & 5 & 6 & 7 & 8 & 9 & 10 & 11 & 12 & 13 & 14 & 15 & 16 & 17 & 18 \\
\hline $1 / 0^{\circ}$ & 0 & & & & & & & & & & & & & & & & & & \\
\hline $2 / 0^{\circ}$ & 6 & & & & & & & & & & & & & & & & & & \\
\hline $3 / 0^{\circ}$ & 10 & & & & & & & & & & & & & & & & & & \\
\hline $4 / 0^{\circ}$ & 15 & & & & & & & & & & & & & & & & & & \\
\hline $5 / 45^{\circ}$ & 10 & & & & & & & & & & & & & & & & & & \\
\hline $6 / 0^{\circ}$ & 16 & & & & & & & & & & & & & & & & & & \\
\hline
\end{tabular}

where: blue cells represent reinforced layers and white cells - matrix. $45^{\circ}$ means series with fibers oriented at angle of $45^{\circ}$ to the longitudinal axis of the sample.

The carbon fiber content has been calculated for all variants. For every series 3 test specimens were prepared. The rest of process parameters were constant for all series. Samples were fabricated in use of rectangular filling method. Specimens without the use of supports and the thin-walls support mode were printed. The print resolution was equal to $0.125 \mathrm{~mm}$. The matrix fill density was set at $100 \%$. The number of matrix material traces at the outline of each layer was 2 . Two temperature values of the working chamber, $35^{\circ} \mathrm{C}$ and $65^{\circ} \mathrm{C}$, were used. The higher temperature setting was dictated by the fact that the Mark Two device has a protection causing that the device stops operating (working) when the chamber reaches temperature equal to $70^{\circ} \mathrm{C}$. The obtained samples were dried due to the hygroscopic properties of the polyamide. Drying was performed at the temperature equal to $80^{\circ} \mathrm{C}$ and lasted 4 hours. Then, the tensile strength $\left(R_{m}\right)$, modulus of elasticity $(E)$ and elongation at break $\left(\varepsilon_{\mathrm{r}}\right)$ were determined for all variants of the samples in a static tensile test, using the Z030 testing machine (Zwick/Roell, Germany). The test was carried out in accordance to the PN EN ISO 527-1: 2012 standard. To determine the Young's modulus, the tensile speed was set at $1 \mathrm{~mm} / \mathrm{min}$, and after its value was calculated, the test speed increased to $50 \pm 1 \mathrm{~mm} / \mathrm{min}$. The initial distance between the sample holders of the test machine was $50 \mathrm{~mm}$. 


\section{Results}

Similarly to the composites based on duroplastic matrix, a significant dependence of the tensile strength and Young's modulus on the content of continuous fibers in the polyamide matrix was stated. In the case of series 6 specimens, which were made with the largest number of 16 reinforcement layers, the maximum value of tensile strength and of Young's modulus were obtained (Tab. 2). These excellent values resulted from the fact that fibers were arranged parallel to the tensile force. The change of application direction of continuous fiber reinforced paths by an angle of $45^{\circ}$ caused a 6 -fold decrease of strength (Tab. 2, series 3 and 5). Therefore, the phenomenon of the necessity to arrange the fibers in the direction of the external load, known for duroplastic composites, was confirmed [15-16]. Changing the resin matrix to a polyamide one revealed this fact even more clearly. The tensile strength obtained at the temperature of $35^{\circ} \mathrm{C}$ for the $\mathrm{PA} / \mathrm{CF}$ composite containing $39 \%$ by volume of fibrous filler $\mathrm{R}_{\mathrm{m}}=427.3 \pm 5.4 \mathrm{MPa}$ is comparable to the aluminium and carbon steel alloys. The low value of standard deviation proves the very good repeatability of the specimens produced by the CFF method, as well as the good transmission of the external load through the PA matrix to the reinforcing fibers. For series 6, above average results of Young's modulus $E=20233$ $\pm 125 \mathrm{MPa}$ and elongation $\varepsilon_{\mathrm{r}}=13.10 \pm 5.04 \%$ were also obtained. The two-digit result of the $\varepsilon_{\mathrm{r}}$ parameter shows the good adhesion during the application of successive paths of the molten material and good bonding of subsequent layers. The relative elongation of thermoplastic composites containing a similar volume contribution of cut short fibers is much lower, about few percent [17-18]. The obtained $R_{m}$ value for series 6 samples is more than $50 \%$ of the value declared by the manufacturer. The analysis of the results of a specimen $100 \%$ filled with polyamide shows that they are not interesting (Table 2, series 1) in comparison to material fabricated by the injection method. In particular Young's modulus of PA specimens is 4 times lower than of polyamide standard molded parts.

Table 2. The influence of the content of reinforcement layers and the direction of continuous carbon fibers application on the properties determined in the static tensile test.

\begin{tabular}{cccc}
\hline $\begin{array}{c}\text { Series } \\
\text { number }\end{array}$ & $\begin{array}{c}\text { Tensile Strength } \\
{[\mathrm{M} \mathrm{Pa}]}\end{array}$ & $\begin{array}{c}\text { Young's Modulus } \\
{[\mathrm{M} \mathrm{Pa}]}\end{array}$ & $\begin{array}{c}\text { Elongation at break } \\
{[\%]}\end{array}$ \\
\hline 1 & $44.5 \pm 0.3$ & $419 \pm 4$ & $261.87 \pm 10.84$ \\
2 & $193.7 \pm 3.4$ & $8410 \pm 265$ & $3.83 \pm 0.21$ \\
3 & $289.7 \pm 35.2$ & $13433 \pm 309$ & $4.53 \pm 0.54$ \\
4 & $332.7 \pm 11.67$ & $15733 \pm 340$ & $5.20 \pm 0.24$ \\
5 & $50.4 \pm 2.2$ & $6103 \pm 192$ & $4.73 \pm 0.57$ \\
6 & $427.3 \pm 5.4$ & $20233 \pm 125$ & $13.10 \pm 5.04$ \\
\hline
\end{tabular}

The increase of chamber temperature to the value of $65^{\circ} \mathrm{C}$ did not result in the expected improvement of the composite's properties, but caused their decrease (Table 3). Only the series 4 (15 reinforcement layers) indicated a slight improvement in tensile strength and Young's modulus. On the other hand, an increase of the relative elongation for 5 out of 6 series of samples was noted. That fact is an important premise for carrying out further research towards applying subsequent layers of material in conditions of significantly elevated temperature in the device chamber. For series no. 2-5, increases in the value of elongation at break were recorded at the values of $216 \%, 11 \%, 15 \%$, and $155 \%$, respectively.

It seems that the used device is not factory-adapted to this type of operation, which could result in the disruptions of the printing head's work or the control system during the application of subsequent layers. This thread requires further research and, above all, structure analysis using the DSC (differential scanning calorimetry) method, optical and scanning microscopy and computed tomography. 
Table 3. The comparison of properties of PA/CF composites manufactured in various values of working chamber temperature in the use of CFF additive method.

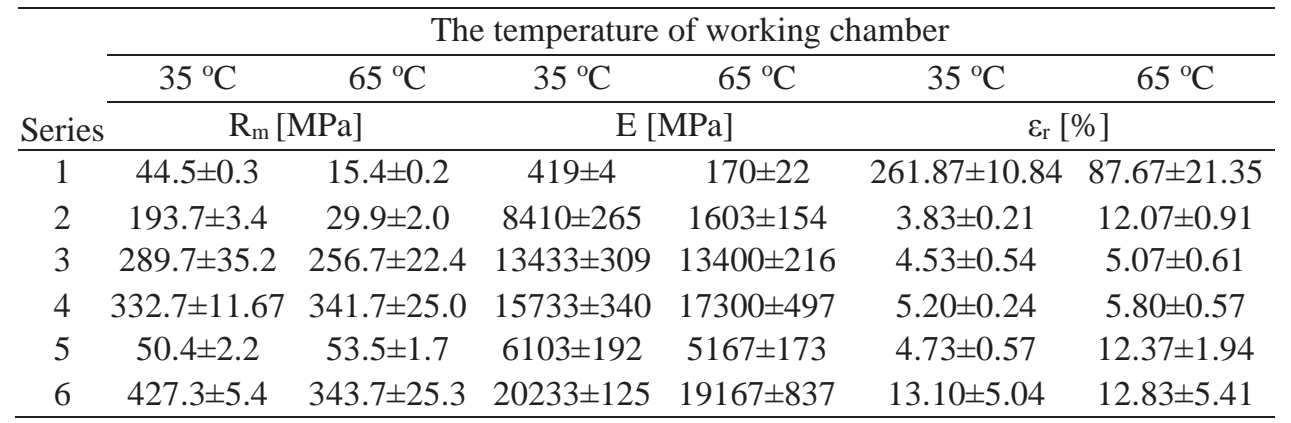

The graphs posted below (Fig. 4, Fig. 5) present the relation between the volume content of continuous fibers in PA/CF composites obtained by the CFF additive technique on their tensile strength and Young's modulus.

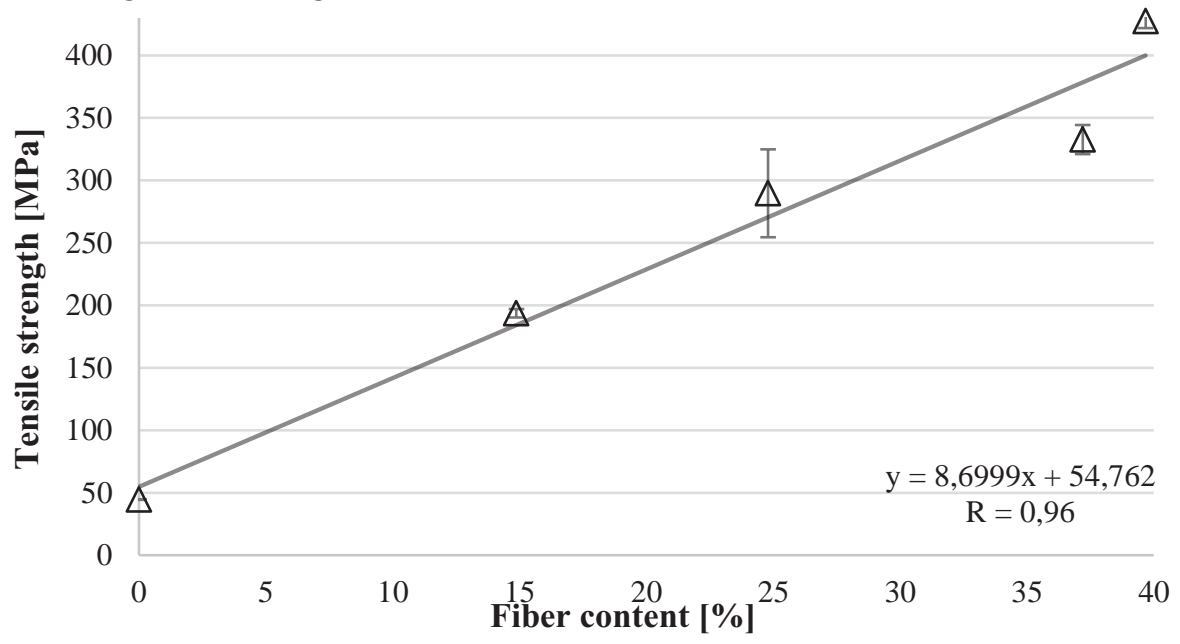

Fig. 4. Effect of the content of continuous carbon fibers oriented parallel to the tensile forces on composite's tensile strength.

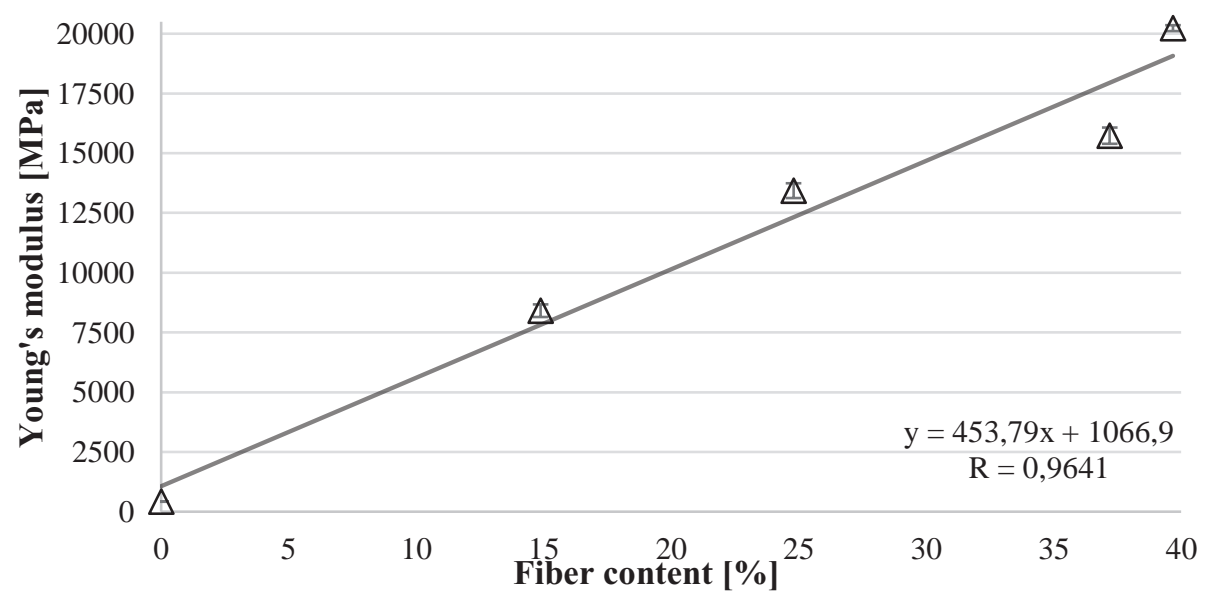

Fig. 5. Effect of the content of continuous carbon fibers oriented parallel to the tensile forces on composite's longitudinal elastic modulus. 
A proportional increase of both strength parameters in relation to the fibrous filler content was found. The high value of the $\mathrm{R}$ correlation coefficient for both straight lines is an indication for further work aimed at improving both strength parameters as a result of applying a larger content of continuous fibers into a polyamide matrix.

This task will be difficult because each fiber is coated the thin polymer layer. The determined regression straight line allows the design of the composition and the number of reinforcement layers for PA/CF composites obtained in CFF technology with the use of the Mark Two device, within the tested range of reinforcing filler content (up to 39\%).

\section{Conclusions}

As a part of the conducted research, PA/CF composites by the CFF additive technique with the use of continuous fibers were manufactured. It was confirmed that the fiber's content and orientation in relation to the tensile force has a significant impact on the strength properties determined in the static tensile test. The results of $\mathrm{Rm}$ and $\mathrm{E}$ obtained for the series 3, 4 and in particular 6 are close or comparable to the aluminium. Due to much lower density of manufactured PA/CF materials, they are an alternative in the field of lightweight engineering materials. This thread is in line with the current trends in materials engineering and design of structural products. The maximum values of the tensile strength $\mathrm{R}_{\mathrm{m}}=427.3 \pm$ $5.4 \mathrm{MPa}$ and the Young's modulus $\mathrm{E}=20233 \pm 125 \mathrm{MPa}$ show the potential application area of continuous fibers for reinforcing of thermoplastics. However, this task requires the use of thermoplastic processing technologies different from the injection process. One of alternatives could be the creation of CFF additive objects by applying successive layers with the use of filaments. The mechanical properties determined for the PA/CF composites obtained by the CFF method are significantly higher in comparison to the material with the same volume content of short carbon fibers, produced in the high-pressure injection molding process. The importance of the working chamber's temperature of the Mark Two device on the properties of $\mathrm{PA} / \mathrm{CF}$ composites using the CFF additive method was stated. Increasing this process parameter did not induce the expected results but caused decrease of the values of both $\mathrm{R}_{\mathrm{m}}$ and $\mathrm{E}$ for 4 out of five composites. However, both results obtained for the series 4 (15 reinforcement layers) and the noticeable increase in the elongation at break for most samples are a sufficient premise to continue this study. In the case of highly filled composites, the importance of setting fibers into molten polymer and interfacial adhesion increases. The mechanical strength will also be influenced by the interconnection of successive layers and the adhesive connections of adjacent material paths applied in the layer.

\section{References}

1. J. Bieniaś, Struktura i właściwości materiałów kompozytowych, Publushing House of W arsaw University of Technology, Warsaw, (2003)

2. H. Leda, Szklane czy węglowe włókna w kompozytach polimerowych, Kompozyty, 3, 7, 209-215, (2000)

3. A. Boczkowska, J. Kapuściński, Z. Lindemann, D. Witemberg-Perzyk, S. W ojciechowski, Kompozyty, Publishing House of W arsaw University of Technology, W arsaw, (2003)

4. H. Leda, Kompozyty polimerowe z włóknami ciągłymi, Publishing House of Poznan University of Technology, Poznan, (2000)

5. M. Fejdyś, M. Łandwijt, Włókna techniczne wzmacniające materiały kompozytowe, Techniczne Wyroby Włókiennicze, 18, 12-22, (2010)

6. R. Porębska, Wybrane zagadnienia oceny własności mechanicznych kompozytów termoplastycznych, PhD Thesis, Cracow U niversity of Technology, (2008)

7. G. T. Mark, A. S. Gozdz, M ethods for composite filament fabrication in three dimensional printing, Patent US nr 9126365 (2014) 
8. A. S. Alwabel, Effect of Fused Filament Fabrication Process Parameters on the Mechanical Properties of Carbon Fiber Reinforced Polymers, Air Force Institute of Technology, (2017)

9. G. W. M elenka, B. K. O. Cheung, J. S. Schofield, R. Dawson, J. P. Carey, Evaluation and Prediction of the Tensile Properties of Continuous Fiber-Reinforced 3D Printed Structures, Composite Structures, 153, 866-875, (2016)

10. A. N. Dickson, J. N. Barry, K. A . M cD onnell, D. P. Dowling, Fabrication of continuous carbon, glass and Kevlar fibre reinforced polymer composites using additive manufacturing, A dditive M anufacturing, 16, 146-152, (2017)

11. I. S. Bitar, N. T. A boulkhair, R. Leach, 2017, The application of composite throughthickness assessment to additively manufactured structures, 28th A nnual International Solid Freeform Fabrication Symposium, U niversity of Texas, Texas, (2017)

12. M. A raya-Calvo, I. López-Gómez, N. Chamberlain-Simon, J. L. León-Salazarb, T. Guillén-Girónb, J. S. Corrales-Corderob, O. Sánchez-B renesa, Evaluation of compressive and flexural properties of continuous fiber fabrication additive manufacturing technology, A dditive M anufacturing, 22, 157-164, (2018)

13. B. Nowinka, Wpływ zbrojenia na właściwości mechaniczne kompozytów $\mathrm{PA}+\mathrm{CF}+\mathrm{GF}$, wytworzonych w technologii CFF, Engeineer's Thesis, Univeristy of Science and Technology in Bydgoszcz, Bydgoszcz, (2018)

14. M. Jurek, Wytwarzanie kompozytów w technologii przyrostowej CFF (ang. Composite Filament Fabrication), Master's Thesis, Univeristy of Science and Technology in BydgoszCz, Bydgoszcz, (2018)

15. K. Vogel, M. Heinrich, J. U lbricht, H. Elsner, H. J. Feige, J. V ogel, L. K roll, M echanical properties of glass fiber-reinforced composites, XIIIth Youth Symposium on Experimental Solid M echanics, Děčín, (2014)

16. B. Bakir, H. Hashem, Effect of Fiber Orientation for Fiber Glass Reinforced Composite M aterial on M echanical Properties, IJ M M ME, 1, 5, 341-345, (2020)

17. M. Wojciechowska, D. Kwiatkowski, W. Tuzikiewicz, Wpływ włókna szklanego na właściwości mechaniczne i krystaliczność kompozytów POM i PA6, Przetwórstwo Tworzyw, 20, 5, 462-467, (2014)

18. J. Denault, T. V u-K hanh, B. Foster, Tensile properties of injection molded long fiber thermoplastic composites, Polymer Composites, 10, 313-321, (1989) 